\title{
Profitability of Groundnut Production Under Smallholder Farmers in Metekel Zone North Western Ethiopia
}

\author{
Welay Tesfay $^{1^{*}} \quad$ Belete Woundefiraw ${ }^{2}$ \\ Ethiopia Institute of Agriculture Research, Pawe Agricultural Research Center
}

\begin{abstract}
Groundnut is South America origin introduced in to Ethiopia in 1920s which is now grown over all warm climate low land part of the country and used as staple food and valuable cash crops for millions of smallholder Ethiopian farmers. This research aims to provide farm level evidence that could guide informed production decision making. The research tried to identified and estimated of cost component and profitability of groundnut production under smallholder farmers. Enterprise budget and descriptive statistics methods were used to analyze data collected from field records of 80 selected groundnut producer smallholder farmers from two districts. The descriptive statistics revealed that harvesting and pilling of groundnut takes higher labor share and female labor contribution is almost similar with male labor in groundnut production process. The enterprise budget analysis revealed that sample smallholder farmers earned net gross margin of ETB 15,761.26 per hectare from groundnut production. Moreover the benefit cost ratio 2.29 indicated that for every one ETB incurred cost, farmers could earn a benefit of ETB 2.29. In addition to this, the sensitivity analysis indicated that profitability of groundnut is more sensitive to increasing of input price and decreasing of output price than to decreasing input price and increasing of output price simultaneously. Therefore, this paper concluded that groundnut production in Metekel zone of Benshagul gumuz is profitable enterprise. This paper suggests that variety improvement and market linkage between producers and agro-industries would be enhanced production and profitability of groundnut under smallholder farmers.
\end{abstract}

Keywords: Groundnut, Production, Cost, Enterprise budget analysis, profitability and Sensitivity analysis

DOI: $10.7176 /$ RHSS/11-15-01

Publication date:October $31^{\text {st }} 2021$

\section{INTRODUCTION}

Groundnut (Arachis Hypogaea) is a low land edible oil crop which cultivated near 100 countries, which $90 \%$ are developing countries and it uses as staple food and valuable cash crops for millions of households (Pazderka and Emmott, 2010). It is South America origin and introduced in to Eritrea and Ethiopia in 1920s (Haji and Zekeriya, 2016). Groundnut production is one of the most crucial agricultural crop in the world (Taru et al., 2008), adaptability to dry condition, it requires low inputs and makes it suitable crop for tropical and subtropical.

Groundnut is a legume crop which improves soil fertility by fixing atmospheric nitrogen and save fertilizer cost in subsequent crops(Harfe, 2016). This is an option for smallholder farmers who are unable to purchase inorganic fertilizer due to concurrent increment of fertilizer price (Simtowe et al., 2010). In many countries, groundnut used as oil seed, food and animal feeds all over the world which contains digestible protein ( 25 to $34 \%$ ), cooking oil (44 to 56\%), and vitamins like thiamin, riboflavin and niacin. Its cake and haulms (straw stem) are used for livestock feed(Simtowe et al., 2010) .

It is South America origin and introduce into Ethiopia in 1920s, which is now grown over all the warm climate low land area of the country(Haji and Zekeriya, 2016). It is mainly grown in eastern Harerghe and Metekel Zone with immense potential in Gamogofa, Illubabor, West Gojam, North Shoa, North and South Wello, East and West Wellega, and Western Tigray (CSA, 2018). According to the CSA report on area and production of crops, more than 521,326 private peasant holding households have been grown groundnut in 80,841.57 hectares of land in the $2017 / 18$ cropping season leading to a total production of well over 1.45 million quintal (CSA, 2018). According to the same report, Oromia region constitutes the largest proportion of groundnut production areas accounting for $63 \%(328,283 \mathrm{ha})$ and Benishangul Gumz is the second largest contributor in terms of ground nut production areas $(20,033.19 \mathrm{ha})$ out of which more than one half $(17,558.84 \mathrm{ha})$ is found in Metekel zone. Metekel zone is one of the potential groundnuts producing zone in Benshagul Gumuz region, which stood first in terms of area cultivated and groundnut production. It is primary in producing and supplying of groundnut to both domestic and export market in the region. During the 2016/17 cropping season, the zone was produced 357,714.46 quintal of groundnut from 17,558.84 ha of cultivated with average yield of $20.37 \mathrm{qt} / \mathrm{ha}$ (CSA, 2017).

To boost the groundnut production in Metekel zone, Governments and non-governmtal organization have been made tremendous efforts to address the main constraints faced the Groundnut production sector(PARC, 2018). Among the governmental sector Research center takes a lion share on addressing these constraints particularly by innovating new variety that gives high productivity and disease tolerance variety. In line with this Pawe

\footnotetext{
${ }^{1}$ Agricultural Economics Researcher, Pawe Agriculture Research Center

${ }^{2}$ Agricultural Economics Researcher, Pawe Agriculture Research Center
} 
Agricultural research center has been conducted adaptation trials, breeding and demonstration pre scaling and scaling up of Groundnut news variety for the last decades. In collaboration of other research center, it released Maniper varieties and disseminated to end users in Metekel and Awi Zone. These varieties contribute their own role on the smallholder farmers' income increment as well as poverty reduction. Even if, all these efforts has been done the profitability of Groundnut production at household level were not studied yet particularly at Metekel zone. This paper is filled this gap of knowledge and determine the groundnut profitability at household level in Metekel Zone.

\section{Research Methodology}

\subsection{Description of the study area}

The study conducted in Dibate district, Metekel zone Benshangul Gumuz region, North Western Ethiopia. The district is found at $547 \mathrm{Km}$ to North West direction far away from Addis Ababa with geographical location at $36^{0} 12^{\prime} 55.57^{\prime}$ 'longitude and latitude of $10^{0} 39^{\prime} 00.48^{\prime}$ ' It covers an area of 368,289 hectare with estimate population of $67,227(50.80 \%$ male) inhabitants (DDAO, 2018). The farming system of the district is characterized as mixed crop-livestock farming system dominated by cereal and pulses crops. Among the pulses, groundnut takes a lion share in terms of production and area coverage (CSA, 2018). The district is bounded in East by Guangua and Zigem district, in North by Mandura district, in South by Yaso district, in West by Bullen districts. It is characterized as warm humid low land area with high rain fall. The district has 29 kebeles and the climate of the area is hot humid and characterized by unimodal rainfall pattern with high and heavy rainfall that exceeds from May to October. The area receives mean annual rainfall of $1175 \mathrm{~mm}$ and its altitude ranges between 1080 to 1700 $\mathrm{m}$ with mean annual temperature of $15^{\circ} \mathrm{c}$ to $29^{\circ} \mathrm{c}$ which ranges $12^{\circ} \mathrm{c}$ to $32^{\circ} \mathrm{c}$

The study conducted in Dangur district, Metekel zone Benshangul Gumuz region, North Western Ethiopia. The district is found at $570 \mathrm{Km}$ to North Western direction far away from Addis Ababa with geographical location at $36^{\circ} 29^{\prime} 46.40^{\prime \prime}$ ' longitude and latitude of $11^{0} 17^{\prime} 03.90^{\prime \prime}$. It covers an area of 838,700 hectare with estimate population of 70,387(51.13\% male) inhabitants (DDAO, 2018). The farming system of the district is characterized as mixed crop-livestock farming system dominated by cereal and pulses crops. Among the pulses, Groundnut takes a lion share in terms of production and area coverage (CSA, 2018). Dangur district is bounded in East by Pawe district, in South by Bullen, in West by Guba districts and in North by Quara and Jawi districts. It is characterized as warm humid low land area with high rain fall. The district has 29 kebeles and out of these kebeles 26 are groundnut producers. The climate of the area is hot humid and characterized by unimodal rainfall pattern with high and heavy rainfall that exceeds from May to October. The area receives mean annual rainfall of $1250 \mathrm{~mm}$ and its altitude ranges from 800 to 2731 m.a.s.l with mean annual temperature of $16^{\circ} \mathrm{c}$ to $380 \mathrm{c}$ which ranges $12^{\circ} \mathrm{c}$ to 40 ${ }^{0} \mathrm{c}$ Dangur district agricultural office (DDAO, 2018).

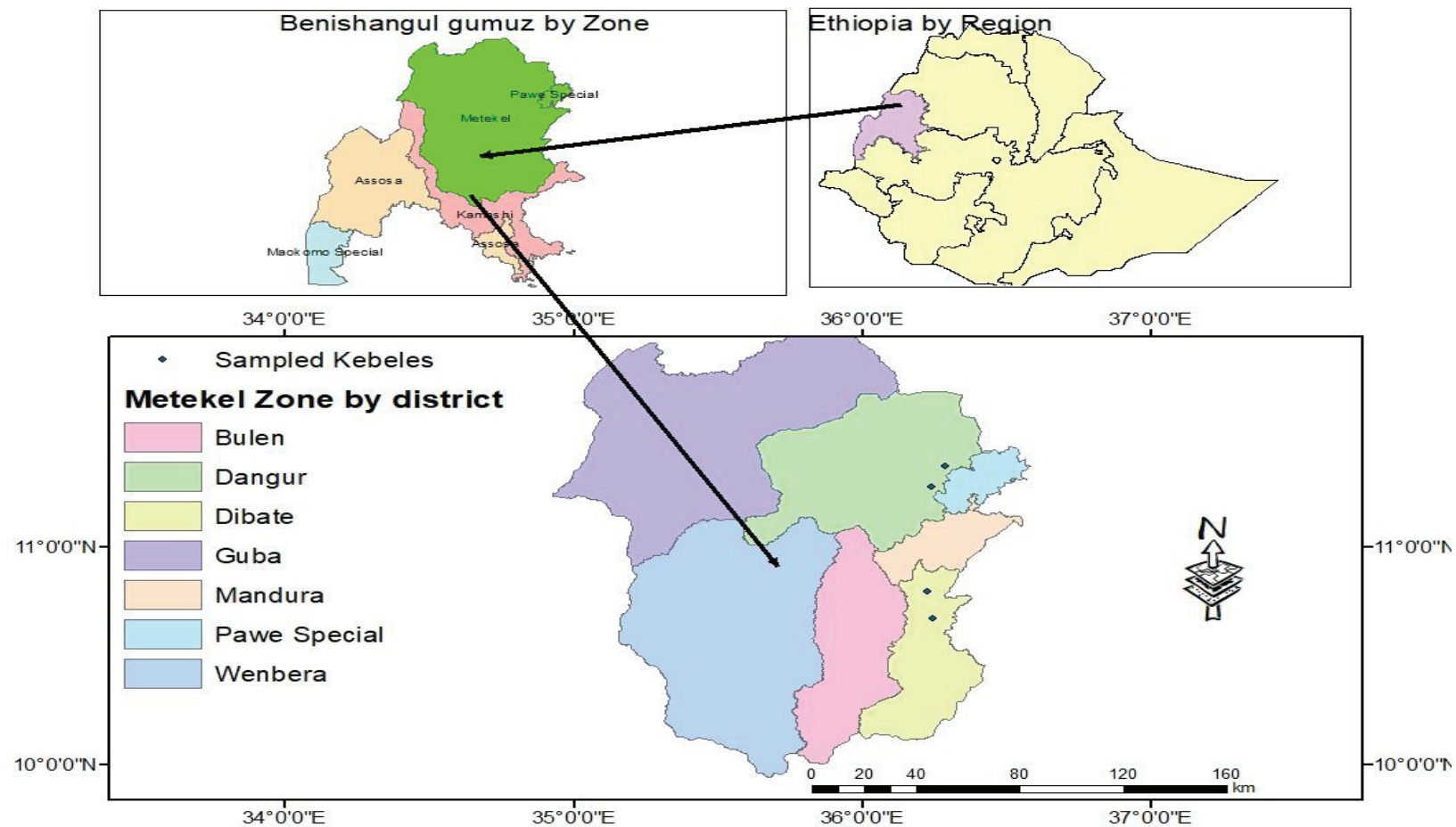

Figure 1 Map of the study area 
Data collection and analysis method

Metekel zone is one of the major groundnuts producing areas in North western of Ethiopia next to eastern of Ethiopia, East and West of Harerge zone. It has sex districts that produced groundnut potentially. Among these district, Dibate and Dangur districts were selected randomly. Two kebles from each district and 20 sample households from each kebeles were selected randomly. Accordingly Parezeit and Sasmandin from Dibate district and Abay kutir 2 and Azareti kitli from dangur district was selected.

The study used both primary and secondary data. The primary data were collected using prepared input output recording format developed by the researches and recorded each farming activities and associated costs with the trained extension agents per weekly. It also regularly supervised by the researchers and take measure and correction actions when mistakes of data taking have been happened. The secondary data were collected from Dibate and Dangur district of agricultural office. Descriptive statistics, frequency, percentage, gross margin and sensitivity analysis were used to analysis the data.

To determine the level of groundnut profitability enterprise budgeting methods was employed. It also used gross margin analysis to determine the cost and return of groundnut production in Metekel zone. The gross margin is simply the difference between total revenue (TR) and Average total variable cost (ATVC). Total revenue is the product of output in qt/ha and its price /qt. Total cost is the sum of total fixed and variable costs. This type of model was used by different Authors to calculate the profitability of different crops. (Ayalew et al., 2018) and (Hagos and Bekele, 2018) used enterprise budget and gross margin analysis to calculate the profitability of soybean in Metekel and Asosa zone of Benshangul gumz regional state, Ethiopia respectively.

Mathematically

$$
\text { Net Gross Margin = Gross Revenue }- \text { Average Total Cost }-------1
$$

\section{Break Even Analysis}

Break even analysis is a useful tool in enterprise analysis to determine the profitability of the enterprise even at worst condition. It also used to fix the minimum output sale price and the minimum amount of outputs to be produced to cover all the average total cost of enterprise production costs. The Mathematical formula of breakeven analysis is given below

$$
\begin{aligned}
& \text { Break - Even Sale Price }=\frac{\text { Average Total Cost }}{\text { Average Production(Yield) }}------2 \\
& \text { Break-Even Yield }=\frac{\text { Average Total Cost }}{\text { Sale Price }}---------3
\end{aligned}
$$

\section{Result and Discussion}

\section{Demographic characteristics' of sample households'}

Most of the sample households were male heads $(92.5 \%)$ and their educational background was at least attained

\begin{tabular}{|c|c|c|}
\hline Variables & Frequency & Percent \\
\hline \multicolumn{3}{|l|}{ Sex of $\mathrm{HHs}$} \\
\hline Male & 74 & 92.5 \\
\hline Female & 6 & 7.5 \\
\hline Total & 80 & 100 \\
\hline \multicolumn{3}{|l|}{ Education of HHs } \\
\hline Illiterate & 30 & 37.5 \\
\hline Read and write & 17 & 21.3 \\
\hline $1-4^{\text {th }}$ grade & 5 & 6.3 \\
\hline $5-8^{\text {th }}$ grade & 18 & 22.5 \\
\hline $9-12^{\text {th }}$ grade & 10 & 12.5 \\
\hline Total & 80 & 100 \\
\hline
\end{tabular}
primary school and above $(41.3 \%)$ with illiterate of $37.5 \%$ and the remains were able to read and write $(21.3 \%)$. Table 1 Sex and Educational background of Sample household heads

Source: Farm level survey, 2019

Socio economic characteristics of sample households'

The groundnut producing sample household heads age was on average 43.98 years old with 22.56 and 12.5 of farming and groundnut producing experience in years in the study area. The result indicated that groundnut is introduced in the area recently. The sample survey indicated that on average 0.92 and 1.92 hectare of land was allocated for groundnut and other crop production respectively. It indicated that groundnut crop is very important 
low land oil crop in the study area. This is due to groundnut is a league crop which needs a least amount of inputs like fertilizer and one or two ploughing frequencies. It is cash crop and main source of income in the study area. Table 2 Farming experience and area allocation of Sample households in Metekel zone

\begin{tabular}{|c|c|c|c|c|}
\hline Variables & Mean & Std.deviation & Min & Max \\
\hline Age of HHs in year & 43.98 & 12.26 & 22 & 78 \\
\hline Farming experience in years & 22.56 & 12 & 1 & 58 \\
\hline Groundnut farming experience in year & 12.5 & 8.10 & 1 & 37 \\
\hline Area allocated for groundnut & 0.92 & 0.52 & 0.25 & 2.5 \\
\hline Area allocated for other crops & 1.92 & 1.34 & 0.25 & 5.5 \\
\hline
\end{tabular}

Source: Farm level survey, 2019

\section{Sample households' Groundnut production in Metekel zone}

Majority of the sample households $(56.25 \%)$ were cultivated one hectare and above for groundnut production while $43.75 \%$ of sample households were cultivated 0.25 to 0.75 hectare of land for groundnut production during the 2018/19 cropping season. Most of them were produced less than $1900 \mathrm{~kg}$ per hectare of groundnut yield which is less than the national average groundnut yield per hectare $(1796 \mathrm{~kg} / \mathrm{ha})$ as well as the Bensgangul Gumuz regional state of groundnut yield $2053 \mathrm{~kg} / \mathrm{ha}$ ( CSA, 2018).

Table 3 Distribution of area under groundnut and attained yield by sample households

\begin{tabular}{ccc} 
Groundnut area(ha) & Frequency & Percent \\
\hline $0.25-0.75$ & 35 & 43.75 \\
$1-1.5$ & 39 & 48.75 \\
$1.75-2.5$ & 6 & 7.5 \\
Groundnut production $(\mathrm{kg})$ & 10 & \\
$252-495$ & 21 & 26.25 \\
$510-924$ & 31 & 38.75 \\
$1,000-1,750$ & 18 & 22.50
\end{tabular}

Source: Farm level survey, 2019

Labor allocation of Sample Household on groundnut farming activities

In developing countries, like Ethiopia most of agricultural activities were done through the unskilled human labor with little combination of modern farm machineries. Groundnut production is among legume crops produced in Ethiopia which takes massive human labor to perform the different farm activities of groundnut. The table below showed that human labor distribution among different Groundnut farming activities disaggregated by sex in north western Ethiopia. According table, Harvesting and piling of groundnut production takes higher labor share $(45.60 \%)$ among different groundnut farming activities. This is due to groundnut seed is matured underground and harvested using small hand tools by digging of the ground. Groundnut harvesting labor can share more than this, if does not rain during harvesting of groundnut due to drying of the groundnut farm and difficult to digging out of the groundnut seed. Next to harvesting and piling, Hoeing and first weeding $(28.73 \%)$ was employed higher labor and followed by second weeding(11.69\%), planting (8.16\%) and land clearing and first plough(5.82\%) from the total of 8938 man-days labor used for groundnut farming activities. Female labor is almost participated in all groundnut farming activities which shares $(47.09 \%)$ even their labor contribution were higher than male farmers in hoeing and first weeding (14.77\%), relatively the same and followed by harvesting and pilling (22.29\%). These groundnut farming activities are relatively labor intensive and mostly accomplished by men and women human labor in the study area.

Table 4 Labor distribution among different groundnut farming activities in Metekel zone

\begin{tabular}{|c|c|c|c|c|c|}
\hline Farming activities & $\begin{array}{l}\text { Labor-day } \\
\text { Male }\end{array}$ & Female & Male $\%$ & Female $\%$ & Total $\%$ share \\
\hline Land clearing and first plough & 385 & 135 & 4.31 & 1.51 & 5.82 \\
\hline Planting & 413 & 316 & 4.62 & 3.54 & 8.16 \\
\hline Hoeing and First weeding & 1,248 & 1,320 & 13.96 & 14.77 & 28.73 \\
\hline Second weeding & 599 & 446 & 6.70 & 4.99 & 11.69 \\
\hline Harvesting and Piling & 2,084 & 1,992 & 23.32 & 22.29 & 45.60 \\
\hline Total & 4729 & 4,209 & 52.91 & 47.09 & 100 \\
\hline
\end{tabular}

Source: Farm level survey, 2019 
Number of paired Oxen day labor used in groundnut farming activities

Groundnut farming in Metekel zone is common and sowing at least with one plough and at most with the second ploughing frequency. According the field level data, on average 5 and 3.82 paired oxen day was used in first ploughing and sowing of groundnut farming activities in Metekel zone.

Table 5 Oxen day used in groundnut farming in Metekel Zone

\begin{tabular}{|c|c|c|c|c|}
\hline \multirow[t]{2}{*}{ Farming activities } & \multicolumn{4}{|c|}{ Paired Oxen per day } \\
\hline & Mean & Std.dev & Min & Max \\
\hline First ploughing & 5 & 2 & 1 & 10 \\
\hline Sowing & 3.82 & 2.05 & 1 & 10 \\
\hline
\end{tabular}

Source: Farm level survey, 2019

\section{Sample households types of cost incurred in groundnut production}

Mixed farming is the base of smallholder farmer livelihood in Metekel zone. They are practicing both livestock rearing and crop production at the same time. Both animal rearing and crop production needs wisely allocation of labor, land, capital and light farm tools. Groundnut is among low land oil crops which potentially produced in Metekel zone. Sample households were combined different inputs to produce groundnut yield. Some of them were human labor, oxen labor, land, seed of groundnut and small farm tools like shovel, hoe and oxen materials. Sample households were combined these inputs and incurred associate farm input costs to produce groundnut yield. Sample households incurred two different types of costs, farm operation and material costs. The farm operation costs share $83.13 \%$ from total costs incurred by sample households' in producing of groundnut. Among the farm operation costs harvesting and piling costs takes higher share $23.75 \%$ and followed by ploughing cost ( 19.82), hoeing and first weeding $(15.35 \%)$, second weeding $(8.74 \%)$, Hatchery price $(7.62 \%)$, planting $(3.97)$ and land clearing $(2.5 \%)$ respectively. The cost of material was share $16.87 \%$ from the total cost incurred by sample households with $14.52 \%$ of seed cost and remain $2.35 \%$ costs of bags.

Table 6 estimated cost of Groundnut production in Metekel zone

\begin{tabular}{cccccc} 
Types costs incurred & Mean & Std.dev & Min & Max & Total share in \% \\
\hline Cost of Material & $1,879.30$ & 938.76 & 500 & 4,620 & 16.87 \\
Seed cost & 304.80 & 188.21 & 60 & 840 & 2.35 \\
Bag cost & & & & & 83.13 \\
Cost of farm operation & 323.22 & 287.02 & 30 & 1,680 & 2.50 \\
Land clearing & 513.63 & 368.27 & 80 & 2,400 & 3.97 \\
Planting & 2,565 & $1,879.70$ & 400 & 8,000 & 19.82 \\
Ploughing & 180 & 91.15 & 60 & 360 & 1.39 \\
Chemical spring & $1,986.65$ & $1,304.60$ & 140 & 6,000 & 15.35 \\
Hoeing and First weeding & $1,131.14$ & 848.94 & 240 & 3,600 & 8.74 \\
Second weeding & $3,074.63$ & $1,514.69$ & 780 & 10,400 & 23.75 \\
Harvesting and piling & 986.33 & 628.92 & 120 & 3,200 & 7.62 \\
Hatchery price & $12,240.33$ & $5,196.40$ & 3,374 & 2,4400 & 100 \\
Total Average cost & & & &
\end{tabular}

Source: Farm level survey, 2019

\section{Profitability of groundnut production In Metekel Zone}

The sampled households average groundnut yield production was $1306.42 \mathrm{Kg} / \mathrm{ha}$ in Metekel zone which is far lower than the maximum yield obtained from improved groundnut variety $6000 \mathrm{~kg} / \mathrm{ha}$ at research center. This is due to sample households were used local groundnut races, poor agronomic practices and lack of appropriate fertilizer use especially phosphorus fertilizer which used for nodule formation, good seed formation, promote root growth and enhance nutrient and water use efficiency (Harfe, 2016). It obtained $3765.01 \mathrm{~kg} / \mathrm{ha}$ of groundnut with $20 \mathrm{~kg}$ /ha of phosphorus fertilizer application. The sampled households were attained 252 to $35 \mathrm{ookg} / \mathrm{ha}$ yield of groundnut Due to abiotic, biotic and agronomic practices during 2018/19cropping season. The result indicated that, there is an option to double the yield of groundnut yield per ha at smallholder farmers through adopting of improved groundnut variety and recommended agronomic practices.

On average groundnut yield was sold $20.13 \mathrm{birr} / \mathrm{kg}$ with minimum 12 and maximum $23 \mathrm{birr} / \mathrm{kg}$ during 2018/19 cropping season. The price fluctuation is mainly due to form of selling, which sold their unshelled groundnut yield at $12 \mathrm{birr} / \mathrm{kg}$ and sold shelled groundnut yield at $23 \mathrm{birr} / \mathrm{kg}$ especially manually shelled groundnut yield was sold at higher price than shelled by machine. This implies that sample households in the study area can maximize their return of groundnut profit by value adding of their products through hatchery of groundnut either manually or machine which shelled groundnut yield sold at higher price than unshelled groundnut yield. 
The gross margin result indicated that groundnut producers in Metekel zone were gained 15,761.26 birr/ha of profit during 2018/19 cropping season. This implies that groundnut production in Metekel zone is a profitable enterprise at smallholder farmer levels within the current productivity level of groundnut and its output price.

Table 7 Profitability of groundnut production under smallholder farmers in Metekel zone

\begin{tabular}{|c|c|c|c|c|}
\hline Variable & Mean & Std & Min & Max \\
\hline Yield & 1306.42 & 754.06 & 252 & 3500 \\
\hline Unit price & 20.23 & 3.16 & 12 & 23 \\
\hline Gross Revenue & $28,001.58$ & $16,821.87$ & 5,200 & 77,000 \\
\hline Total Fixed cost & $1,879.30$ & 938.76 & 500 & 4,620 \\
\hline Total Variable cost & $10,361.03$ & $4,410.81$ & 2,824 & 20,400 \\
\hline Total cost & $12,240.33$ & $5,196.40$ & 3374 & 24,400 \\
\hline Net Revenue & $15,761.26$ & $12,876.49$ & $-6,268.7)$ & 52,960 \\
\hline CBR & 2.29 & & & \\
\hline
\end{tabular}

Source: Farm level survey, 2019

\section{Break even analysis of groundnut production in Metekel Zone}

Break even analysis of an enterprise has an ability to determine the minimum break even sale price of the outputs and break even yield of an enterprises' outputs to continue the enterprise as business institution without profit loss. The groundnut production break even analysis in Metekel zone revealed that, the break even sale price of groundnut to cover all total average costs of groundnut production was 9.37 as well as the breakeven yield of groundnut yield was $605.06 \mathrm{~kg} / \mathrm{ha}$ of groundnut yield to cover all total average cost of groundnut production in the study area. Therefore, smallholder groundnut producers as enterprise managers should be produced at least $605.06 \mathrm{~kg} / \mathrm{ha}$ shelled groundnut yield and set groundnut shelled yield at $9.37 \mathrm{birr} / \mathrm{kg}$ and above to save the enterprise from profit losing Table(8).

Table 8 Break even analysis of groundnut production in Metekel Zone

\begin{tabular}{|c|c|c|c|c|}
\hline Variable & Mean & Std & Min & Max \\
\hline Yield & $1,306.42$ & 754.06 & 252 & 3,500 \\
\hline Unit price & 20.23 & 3.16 & 12 & 23 \\
\hline Total cost & $12,240.33$ & $5,196.40$ & 3374 & 24,400 \\
\hline
\end{tabular}

Source: Farm level survey, 2019

\section{Sensitivity analysis of groundnut production in Metekel zone}

Agriculture sector is highly sensitive to weather fluctuation especially in developing countries. Ethiopia is one of the developing countries, which its agricultural activities is based on rain fed agriculture. Almost all smallholder farmers, in Ethiopia practice their crop production under rain fed agriculture. Rain fed cropping system is more severe and uncertain to weather fluctuation as well as fluctuated input and output price of agriculture commodities. In addition to this the yields of agricultural commodities is highly affected and depend on the shortage of water faced during different growth stage of the crop. Hence, considering of these factors during planning and implementing of crop enterprise under rain fed agriculture is very important to minimize risk and to show the profitability of the crop production enterprise under fluctuated weather condition and as well as fluctuated input and output agricultural commodity prices'. However, Bad weather condition can be affected the rain fed crop production up to $100 \%$ and rain fed based crop enterprise can get loss $100 \%$. Therefore, what is the profitability level and response of groundnut production, if groundnut production input materials and groundnut yield price is increased and decreased simultaneously and the productivity of groundnut being considered as constant? The sensitivity analysis showed that groundnut profitability is decreased by $30 \%$ and $55.35 \%$, when the total average cost of groundnut increase by 10 and $20 \%$ and groundnut output price decrease by 10 and $20 \%$ respectively. It also showed that groundnut profitability is increased by $19.64 \%$ and $44.63 \%$, when the total average cost of groundnut decreased by 10 and $20 \%$ and groundnut output price increased by 10 and $20 \%$ respectively. This implies that groundnut enterprise is still profitable at fluctuated input and output price of groundnut yield and it is more sensitive to input price increment and output price decreasing than input price decreasing and output price increasing simultaneously the result is in line with (Hagos and Bekele, 2018). 
Table 9 Sensitivity analysis of groundnut production enterprise in Metekel zone when the price of groundnut decrease and Total average cost increase by 10 and 20 at same time, what happen to groundnut profitability

\begin{tabular}{|c|c|c|c|}
\hline Variables & Baseline output & Mean & std \\
\hline Profit & $15,761.26$ & $15,761.26$ & $12,876.49$ \\
\hline Unit price & 20.23 & 20.23 & 3.16 \\
\hline Yield price decrease by $10 \%$ & & 18.21 & 2.84 \\
\hline Yield price decrease by $20 \%$ & & 16.19 & 2.53 \\
\hline Total average cost increase by $10 \%$ & & $13,464.36$ & $5,716.04$ \\
\hline Total average cost increase by $20 \%$ & & $14,688.39$ & $6,235.68$ \\
\hline Revenue 1 & & $24,441.38$ & $15,596.42$ \\
\hline Revenue 2 & & $21,725.67$ & $13,863.48$ \\
\hline Profit 1 & & $10,977.02$ & $11,339.17$ \\
\hline Profit 2 & & $7,037.28$ & $9,391.50$ \\
\hline Profit $1 \%$ change & & 30.35 & \\
\hline Profit $2 \%$ change & & 55.35 & \\
\hline
\end{tabular}

Source: Farm level survey

Table 10 Sensitivity analysis of groundnut production enterprise in Metekel zone when the price of groundnut increase and Total average cost decrease by 10 and $20 \%$ at same time, what happen to groundnut profitability

\begin{tabular}{|c|c|c|c|}
\hline Variables & Baseline output & Mean & std \\
\hline Profit & $15,761.26$ & $15,761.26$ & $12,876.49$ \\
\hline Unit price & 20.23 & 20.23 & 3.16 \\
\hline Yield price increase by $10 \%$ & & 22.25 & 3.48 \\
\hline Yield price increase by $20 \%$ & & 24.28 & 3.79 \\
\hline Total average cost decrease by $10 \%$ & & $11,016.29$ & $4,676.76$ \\
\hline Total average cost decrease by $20 \%$ & & $9,792.26$ & $4,157.12$ \\
\hline Revenue 1 & & $29,872.80$ & $19,062.29$ \\
\hline Revenue 2 & & $32,588.51$ & $20,795.22$ \\
\hline Profit 1 & & $18,856.51$ & $15,423.95$ \\
\hline Profit 2 & & $22,796.25$ & $17,516.95$ \\
\hline Profit $1 \%$ change & & 19.64 & \\
\hline Profit $2 \%$ change & & 44.63 & \\
\hline
\end{tabular}

Source: Farm level survey, 2019

\section{Summary and conclusion}

Groundnut is introduced to Metekel zone, Benshangul region during the settlement program in 1985. Groundnut is cash crop and becomes the main income source to smallholder farmers in the study area.it is labor intensive that created job opportunities for smallholder farmers, daily laborer, Assembler, broker, retailer, whole seller and processors. The main objective this study was to determine the profitability of groundnut enterprise under smallholder farmer level in Metekel zone. To meet its objective, it was taken 80 sample households from Dibate and Dangur district randomly. The majority of the respondents were male headed $(92.5 \%)$ with educational background of at least attained primary school and above $41.3 \%$ and illiteracy rate of $37.5 \%$. Majority of sample households' age were within the productive age with average farming experience and groundnut production experience of 22.56 and 12.5 years respectively. The respondents were allocated $32.39 \%$ of cultivated land for groundnut out of their total cultivated land with average 0.92 hectare of groundnut area planted during 2018/19 cropping season that indicates its importance in the district.

Human labor, oxen labor, hoe, land, seed and oxen materials were used in the groundnut production process. Among these, Human labor takes the lion share with 8938 labor days. Female labor participated in all groundnut farming activities and shares $47.09 \%$ with greater labor contribution than male in hoeing and first weeding of groundnut farming activities. The groundnut enterprise was expended material and operational costs. Farm operational costs were taken $83.13 \%$ out of the total average variable cost. Among farming operation costs, harvesting and piling costs was taken higher share (23.75\%) and followed by ploughing (19.82), hoeing and first weeding (15.35), second weeding $(8.74 \%)$ and hatchery price $(7.62 \%)$.

The sample households average groundnut production was $1306.42 \mathrm{~kg} / \mathrm{ha}$ and sold their products with average sale price of $20.23 \mathrm{birr} / \mathrm{kg}$. The production of $1306.42 \mathrm{~kg} / \mathrm{ha}$ groundnut were expended 12,240.33 birr of total cost on average. Sample households were earned 15,761.26 birr/ha profit at the current productivity and groundnut yield price. The sensitivity analysis indicated that groundnut production more sensitive to input price increase and output price decrease than input price decrease and output price increase simultaneously. It also 
indicated that, it is even profitable at fluctuated input and output prices that earned 7,037.28 to 22,796.25 birr/ha of profit.

\section{Reference}

Ayalew, B., Bekele, A., Mazengia, Y., 2018. Analysis of Cost and Return of Soybean Production Under Small Holder Farmers in Pawe District, North Western Ethiopia. Journal of Natural Sciences Research 8, 28-34.

CSA(Centeral Statistics Agency), 2017. Area and production of major crops Centeral Statistics, Government of Ethiopia..

CSA(Centeral Statistics Agency), 2018. Area and production of major crops Centeral Statistics, Government of Ethiopia.

DDAO(Dibate district Agricultural Office), 2018. Annual Agricultural activities performance report.

Hagos, A., Bekele, A., 2018. Cost and returns of soybean production in Assosa Zone of Benishangul Gumuz Region of Ethiopia.

Haji, J., Zekeriya, M.A., 2016. Economic Efficiency of Groundnut (Arachis hypogaea L.) Production: The Case of Gursum District, East Hararghe Zone, Oromia National Regional State, Ethiopia. Haramaya University.

Harfe, B.S.G.T.M., 2016. Response of groundnut (Arachis hypogaea L.) to different rates of phosphorus fertilizer at Tanqua- Abergelle District, Northern Ethiopia. Basic Research Journal of Agricultural Science and Review Vol 5, 24-29.

PARC, 2018. Annual Report of Pawe Agricultural Research Center. Pawe,Ethiopia.

Pazderka, C., Emmott, A., 2010. Chatham House Procurement for Development Forum: Groundnuts Case Study. Chatham house 10

Simtowe, F., Asfaw, S., Shiferaw, B., Siambi, M., Monyo, E., Muricho, G., Abate, T., Silim, S., Ganga Rao, N., Madzonga, O., 2010. Socioeconomic Assessment of Pigeonpea and Groundnut Production ConditionsFarmer Technology Choice, Market Linkages, Institutions and Poverty in Rural Malawi.

Taru, V., Kyagya, I., Mshelia, S., Adebayo, E., 2008. Economic efficiency of resource use in groundnut production in Adamawa State of Nigeria. World Journal of Agricultural Sciences 4, 896-900. 